\title{
Study on the Effect of Avocado on Apoptosis, Oxidative Stress and Injuries Induced by Diethyl Nitrosamine in Rat Liver
}

\author{
Asmaa F. Hamouda \\ Departement of Biochemistry, Faculty of Science, University of Alexandria, Alexandria 2111, Egypt
}

\begin{abstract}
Avocado (persea americana) has antioxidant, anti inflammatory, anti obesity, anticancer effects. The effect of AVOE (avocado extract) on liver TNF- $\alpha$ (tumor necrosis factor- $\alpha$ ), COX-2 (cyclooxygenase-2), LOX (lipoxygenase), caspase-3, DNAF (DNA fragmentation), NO (nitric oxide), MDA (malondialdehyde), TP (total protein) as well as serum lipid profile and liver functions in rats treated and untreated with DEN (diethyl nitrosamine) was studied. The levels of TNF- $\alpha$, COX-2, LOX, caspase-3, DNAF, NO, MDA, $\mathrm{TP}$ as well as serum lipid profile and liver functions showed an elevation in rats treated with DEN as compared to control. Treatment of rats with AVOE pre, during, and post DEN administration improved TNF- $\alpha$, COX-2, LOX, caspase-3, DNAF, NO, MDA, TP levels as well as serum lipid profile and liver functions as compared to DEN, indicates that AVOE reduced oxidative stress, inflammation and apoptosis induced by DEN. Treatment of healthy rats with AVOE only for 30 days not induced oxidative stress, inflammation and apoptosis for normal liver tissues.
\end{abstract}

Key words: Apoptosis, oxidative stress, inflammation, diethylnitrosamine, DNA fragmentation, avocado.

\section{Introduction}

Apoptosis, or programmed cell death, is a normal process of the development and health of multicellular organisms. Cells die in response to a variety of stimuli and during apoptosis they do so in a controlled, regulated fashion. Apoptosis is an important part of the regulation of the immune system. Problems with the regulation of apoptosis have been implicated in a number of diseases such as cancer which characterized by too little apoptosis and inflammation which characterized by too much of the cell death [1]. Apoptosis can be triggered in two principle ways, by toxic chemicals such as DEN (diethylnitrosamine) or injury leading to damage of DNA, other important cellular targets, and activation or inactivation of receptors by growth-regulating signal factors in the organism [2]. DEN causes a variety of hepatocellular

Corresponding author: Asmaa F. Hamouda, Ph.D., assistant professor in the Umm al-Qura University in Mecca in Saudi Arabia, research field: biochemistry faculty of science. E-mail: asmaakingdom1@yahoo.com. injuries including necrosis, DNA damage, cirrhosis, hypertrophy and hepatic carcinoma [3]. It has been found that DEN distributed in many processed food including meats; tobacco smoke; whisky; smoked, salted, and dried fish; cheese; cured meat; and alcoholic beverages [4].

Avocados (persea americana ), a widely consumed fruit, have been reported to exhibit medicinal effects toward many diseases including liver, skin, arthritis, obesity, and cancer due to a high content of phytochemicals with potential chemopreventive activity [5]. The health benefits effect of avocado may be due to its content of essential nutrients, monounsaturated, oleic acid, and polyunsaturated fats linoleic and linolenic acids, and potentially cancer-preventing phytochemicals (polyphenols, proanthocyanidins, tocopherols, carotenoids, $\beta$-sitosterol, $\beta$-carotene, lecithin, minerals, and vitamins A, C, D, and E) [6-8]. Avocados also are devoid of sodium and are low in calories, carbohydrates, and saturated fats [5]. Studies in humans and animal models 
have showed that it helps to control weight, reduces the risk of diabetes, normalizes blood cholesterol levels, and is involved in liver metabolism [9].

The aim of this study included on: 1) study the effect of DEN (diethyl nitrosamine) and on normal liver. 2) study the effect and chemoprevention of AVOE (avocado extract) against DEN. 3) Study the effect of AVOE on normal liver. The studies focused on the changes in liver TNF- $\alpha$ (tumor necrosis factor- $\alpha$ ), COX-2 (cyclooxygenase-2), LOX (lipoxygenase), caspase-3, DNAF (DNA fragmentation), NO (nitric oxide), MDA (malondialdehyde), total protein as well as serum lipid profile and liver functions. The histopathological studies also were examined.

\section{Materials and Methods}

\subsection{Chemicals}

Kit for caspases-3 assay was obtained from Bio Source International, Inc, 542 Flynn road Camarillo, California 93012 USA. Cayman's COX activity assay kit Catalog No.76015. RayBio Rat TNF- $\alpha$ ELISA Kit, Catalog No. ELR-TNFalpha-001C. Proteinase K from (Finnymesoy. Keilaranta 16A, 02150 ESPOO, Finland.), Sulphanilamide, N-1-Napthyl ethylene diamine, Standard sodium nitrite, SDS (sodium dodecyle sulfate), DEN (Diethylnitrosamine), Highly purified arachidonic acid, Ethidium bromide, agarose, TBA (thiobarbituric acid), TMP (tetramethoxypropan) and Diethylene triaminopentaacetic acid were purchased from Sigma-Aldrich, USA.

\subsection{AVOE (Avocado Curd Extracts)}

The cured oil was obtained from avocado purchased from a local market (Egypt).When edible maturity ripe had been reached [10], the avocados were washed and peeled and the seed was removed. Subsequently, the pulp was homogenized using electric blender with water. The obtained viscous slurry like pulp was stored at $4{ }^{\circ} \mathrm{C}$ until used as orally administered to the rats [11].

\subsection{Animals}

Forty adult male Sprague-Dawely rats weighing 100-110 g were used in this study. All rats were examined for health status and their room was designed to maintain the temperature at $25{ }^{\circ} \mathrm{C}$, relative humidity at approximately $50 \%$ and $12 \mathrm{~h}$ light/dark photoperiod for 2 weeks prior to handling. The animals were then housed in stainless-steel cages, given standard diet and water throughout the study and observed daily for abnormal signs. After acclimatization, rats were divided into four groups of ten rats.

Control group (C): untreated rats.

(DEN) group: Rats were injected intraperitoneally, IP, with $200 \mathrm{mg}$ of DEN/kg body mass (bm) as one dose $[3,12]$.

(AVOE) group: Rats were treated orally with a daily dose of AVOE $1 \mathrm{~mL} / \mathrm{kg}$ body mass (bm) for 30 days $[11,13]$.

(AVOE-DEN) group: Rats were treated orally with a daily dose of AVOE $1 \mathrm{~mL} / \mathrm{kg}$ body mass (bm).

At the beginning of the second week, rats were treated with DEN (as described previously) in addition to a daily dose of AVOE until complete 30 days $[3,11$, 12].

At the end of the experimental period, feeding was stopped $12 \mathrm{~h}$ prior to killing. Rats were anaesthetized by diethylether and killed. Livers were removed immediately, and small portions were fixed in $10 \%$ formalin for histopathological examination. The remaining liver tissues were washed with cold saline solution $(0.9 \% \mathrm{NaCl})$, weighed, divided into two parts and kept at $-80{ }^{\circ} \mathrm{C}$ until used for biochemical analysis.

Unheparinized blood samples were collected, kept at room temperature for $15 \mathrm{~min}$ and then sera were separated by centrifugation at $3,000 \mathrm{rpm}$ at $2^{\circ} \mathrm{C}$ for 20 min. Sera were stored at $-30{ }^{\circ} \mathrm{C}$ until used.

\subsection{Biochemical Assay}

\subsubsection{Total Protein Level in Liver}

It was determined by the method of Tsuyosh and James, (1978) [14].

2.4.2 Lipoxygenase (LOX, EC 1.13.11) 
LOX activity in Liver tissues was determined spectrophotometrically (using sodium arachidonate as substrate) according to method of Haining and Axelrod, 1958 [15]. One unit of LOX enzyme is defined as the quantity of the enzyme catalyzing the formation of one $\mu$ mol of hydroperoxyarachidonate (HPA) per min/mg protein under the assay conditions. The extinction coefficient $=25000 \mathrm{M} / \mathrm{L}$.

\subsubsection{Cycolooxygenase (COX-2, EC 1.14.99.1)}

The activity of COX-2 in the liver tissues was assayed using kit according to [16].

\subsubsection{TNF- $\alpha$ (Tumor Necrosis Factor- $\alpha$ )}

TNF- $\alpha$ level in the Liver tissues was determined using rat TNF- $\alpha$ ELISA kit [17].

\subsubsection{Caspase-3 (EC 3.4.22.56)}

Caspase-3 activity in the liver tissues was determined using a colorimetric kit [18]. Fold-increase in caspase-3 activity was determined by direct comparison to the level of the uninduced control.

\subsubsection{DNA Fragmentation}

DNA was isolated using DNA purification kit. Then DNA was separated by electrophoresis on $1 \%$ agarose gel containing ethidium bromide [19].

\subsubsection{NO Level}

It was determined spectrophotometrically [20]. The livers tissues were homogenized in four volumes of cell lysate buffer (pH 7.5). The homogenate was centrifuged at 10,000 $\mathrm{g}$ for one min at $4 \mathrm{oC}$, and the supernatant was stored at $-30{ }^{\circ} \mathrm{C}$ until used. One hundred microliters of sample (liver or standard sodium nitrite $100 \mu \mathrm{M}$ ) were added to $1 \mathrm{~mL}$ of Sulphanilamide, and mixed. Fifty microliters $\mathrm{N}$-1-Napthyl ethylene diamine was added, incubated at room temp. for $20 \mathrm{~min}$ and the absorbance was recorded at $540 \mathrm{~nm}$ against blank (since buffer was added instead of sample).

\subsubsection{Lipid Peroxidation}

Lipid peroxidation was determined calorimetrically by measuring the level of MDA, the end product of lipid peroxidation, according to the method of Ohkawa et al., (1979) [21]. Fifty microliters of the crude homogenate or homogenizing buffer (blank) were incubated with 100 microliters of $8.1 \%$ of SDS, 750 microliters of $20 \%$ acetic acid containing HCL, pH 3.5, 750 microliters of $0.8 \%$ TBA, and 300 microliters of distilled water in boiling water bath for $45 \mathrm{~min}$. After cooling at room temperature, 500 microliters of distilled water and $2.5 \mathrm{~mL}$ of $\mathrm{n}$-butanol/pyridine mixture $(15: 1 \mathrm{v} / \mathrm{v})$ were added, mixed well, and centrifuged for $10 \mathrm{~min}$ at $1,780 \mathrm{~g}$. The absorbance of the pink color was measured at $532 \mathrm{~nm}$ and the concentration of MDA was determined as $\mathrm{nmol} / \mathrm{g}$ liver. Different concentrations of TMP (20-300 nmol) were used as standard and treated in a similar way as the sample.

\subsubsection{Liver Function Test}

Total bilirubin concentration and aminotransferases (AST and ALT) activities were determined according to the methods of Jendrassik and Grof (1938), and Reitman and Frankel (1957), respectively [22, 23].

2.4.10 Lipid Profile

Total cholesterol, LDL-cholesterol, HDL-chloesterol and TG were determined according to the method of Burstein et al., (1970) [24].

\subsubsection{Histopathological Study}

Liver tissues were fixed, processed and embedded in paraffin wax. Sections of $5 \mu \mathrm{m}$ in thickness were cut and stained with hematoxylin and eosin.

\subsubsection{Statistical Analysis}

Statistical analysis: All data are presented as means (X) \pm S.D. (standard deviation). Comparisons between the means of various treatment groups were analyzed using LSD (least significant difference) test. Differences were considered significant at $P<0.05$. All statistical analyses were performed using the statistical software SPSS, version 16.

\section{Results}

\subsection{Total Protein Level in Liver}

The TP (total protein) levels in C (control) were $750.87 \pm 2.51 \mathrm{mg} / \mathrm{g}$, lower than that in DEN group $1,109.67 \pm 2.50 \mathrm{mg} / \mathrm{g} ; P<0.05$. The TP levels in 
AVOE group were $749.97 \pm 3.51 \mathrm{mg} / \mathrm{g}$, compared to C; $P<0.05$. The TP levels in AVOE-DEN were $860.40 \pm$ $3.66 \mathrm{mg} / \mathrm{g}$, compared to DEN; $P<0.05$ (Table. 1).

\subsection{Lipoxygenase Activity in Liver Tissues}

The enzyme levels in control were $0.02 \pm 0.003$ $\mu \mathrm{mol} / \mathrm{mg}$, lower than that in DEN group $0.08 \pm 0.003$ $\mu \mathrm{mol} / \mathrm{mg} ; P<0.05$. The enzyme levels in AVOE group were $0.02 \pm 0.004 \mu \mathrm{mol} / \mathrm{mg}$, compared to $\mathrm{C}$; $P<$ 0.05 . The enzyme levels in AVOE-DEN were $0.03 \pm$ $0.003 \mu \mathrm{mol} / \mathrm{mg}$, compared to DEN; $P<0.05$ (Fig. 1a).

\subsection{Cycolooxygenase in the Liver Tissues}

The enzyme levels in control were $1.94 \pm 0.09 \mathrm{U} / \mathrm{mL}$, lower than that in DEN group $5.08 \pm 0.29 \mathrm{U} / \mathrm{mL} ; P<$ 0.05 . The enzyme levels in AVOE group were $1.93 \pm$ $0.04 \mathrm{U} / \mathrm{mL}$, compared to $C ; P<0.05$. The enzyme levels in AVOE-DEN were $2.43 \pm 0.51 \mathrm{U} / \mathrm{mL}$, compared to DEN; $P<0.05$ (Fig. 1b).

\subsection{TNF- $\alpha$ (Tumor NecrosisFactor- $\alpha$ ) Level}

TNF- $\alpha$ levels in control were $35.06 \pm 1.98 \mathrm{pg} / \mathrm{mL}$ lower than that in DEN group $101.89 \pm 5.01 \mathrm{pg} / \mathrm{mL} ; P$ $<0.05$. TNF- $\alpha$ levels in AVOE group were $35.67 \pm$ $2.75 \mathrm{pg} / \mathrm{mL}$ compared to $\mathrm{C}$; $P<0.05$. TNF- $\alpha$ levels in AVOE-DEN were $46.87 \pm 2.24 \mathrm{pg} / \mathrm{mL}$ compared to DEN; $P<0.05$ (Fig. 1c).

\subsection{Caspase-3 Activity}

The enzyme levels in control were $0.19 \pm 0.03$ lower than that in DEN group $0.87 \pm 0.04 ; P<0.05$. The enzyme levels in AVOE group were $0.20 \pm 0.02$ compared to $\mathrm{C} ; P<0.05$. The enzyme levels in AVOE-DEN were $0.34 \pm 0.03$ compared to DEN; $P<$ 0.05 (Fig. 1d).

\subsection{DNAF (DNA Fragmentation) in Liver Tissue}

The agarose gel electrophoresis showed very low or undetectable DNA laddering (DNAF) in the liver tissue of the Control. The DNA intact band appears to be condensed near the application point with no DNA smearing suggesting no DNAF. Treatment with AVOE alone shows no DNA smearing suggesting no DNAF compared to control. DEN administration resulted in a massive DNAF compared to the $\mathrm{C}$ group. Treatment with AVOE pre, during, and post DEN administration decreased DNAF compared to the DEN group (Fig. 2).

\subsection{Lipid Peroxidation}

MDA levels in control were $2.88 \pm 1.10 \mathrm{nmol} / \mathrm{g}$ lower than that in DEN group $17.16 \pm 1.08 \mathrm{nmol} / \mathrm{g} ; P<$ 0.05. MDA levels in AVOE group were $2.79 \pm 0.45$ nmol/g compared to $\mathrm{C} ; P<0.05$. MDA levels in AVOE-DEN were $2.89 \pm 0.56 \mathrm{nmol} / \mathrm{g}$ compared to DEN; $P<0.05$ (Fig. 1e).

\subsection{NO Level}

NO levels in control were $33.21 \pm 2.99 \mu \mathrm{m}$ lower than that in DEN group $69.82 \pm 2.90 \mu \mathrm{m} ; P<0.05$. NO levels in AVOE group were $31.99 \pm 2.79 \mu \mathrm{m}$ compared to $\mathrm{C} ; P<0.05$. NO levels AVOE-DEN were $36.53 \pm$ $2.76 \mu \mathrm{m}$ compared to DEN; $P<0.05$ (Fig. 1f).

Table 1 Biochemical parameters of different studied groups.

\begin{tabular}{lllll}
\hline Particulars & C & DEN & AVOE-DEN & AVOE \\
\hline Serum & & & & \\
\hline ALT (U/L) & $0.80^{\mathrm{a}} \pm 0.08$ & $4.55^{\mathrm{b}} \pm 0.16$ & $2.47^{\mathrm{c}} \pm 0.29$ & $0.81^{\mathrm{a}} \pm 0.19$ \\
AST (U/L) & $15.41^{\mathrm{a}} \pm 1.29$ & $20.2^{\mathrm{b}} \pm 2.01$ & $16.23^{\mathrm{c}} \pm 1.99$ & $15.44^{\mathrm{a}} \pm 1.71$ \\
Bilirubin (mg/dL) & $0.76^{\mathrm{a}} \pm 0.19$ & $1.99^{\mathrm{b}} \pm 0.08$ & $1.12^{\mathrm{c}} \pm 0.09$ & $0.77^{\mathrm{a}} \pm 0.08$ \\
TC (Total cholesterol) concentration mg/dL) & $66.64^{\mathrm{a}} \pm 3.17$ & $202.99^{\mathrm{b}} \pm 3.02$ & $102.42^{\mathrm{c}} \pm 3.26$ & $65.97^{\mathrm{a}} \pm 2.89$ \\
TG mg/dL & $78.79^{\mathrm{a}} \pm 1.84$ & $168.74^{\mathrm{b}} \pm 2.41$ & $92.71^{\mathrm{c}} \pm 2.26$ & $77.99^{\mathrm{a}} \pm 1.91$ \\
HDL-C (mg/dL) & $22.99^{\mathrm{a}} \pm 1.91$ & $14.14^{\mathrm{b}} \pm 3.42$ & $22.93^{\mathrm{a}} \pm 1.86$ & $23.01^{\mathrm{a}} \pm 1.60$ \\
LDL-C (mg/dL & $35.75^{\mathrm{a}} \pm 0.57$ & $160.80^{\mathrm{b}} \pm 1.02$ & $36.63^{\mathrm{c}} \pm 0.42$ & $34.98^{\mathrm{a}} \pm 0.26$ \\
\hline Tissue & & & & \\
\hline
\end{tabular}




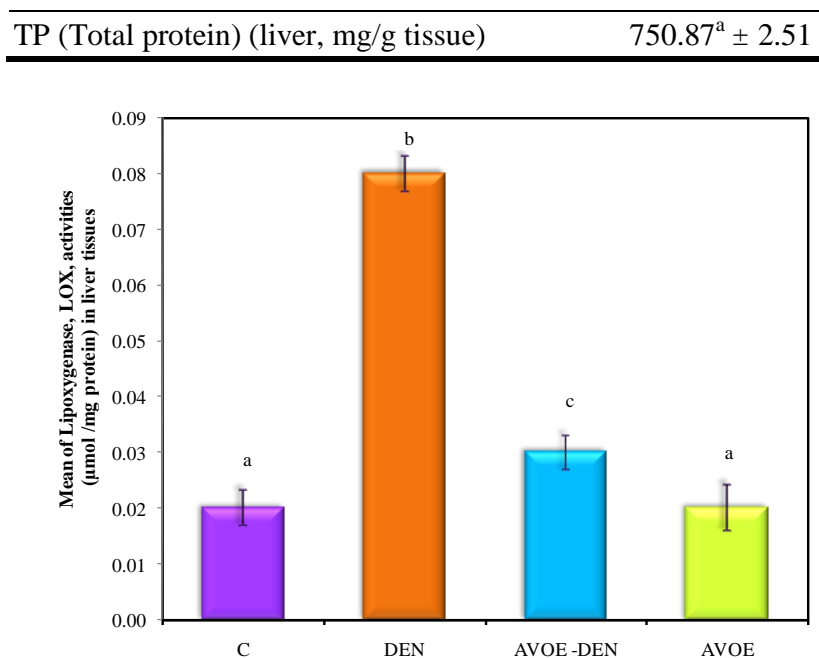

(a)

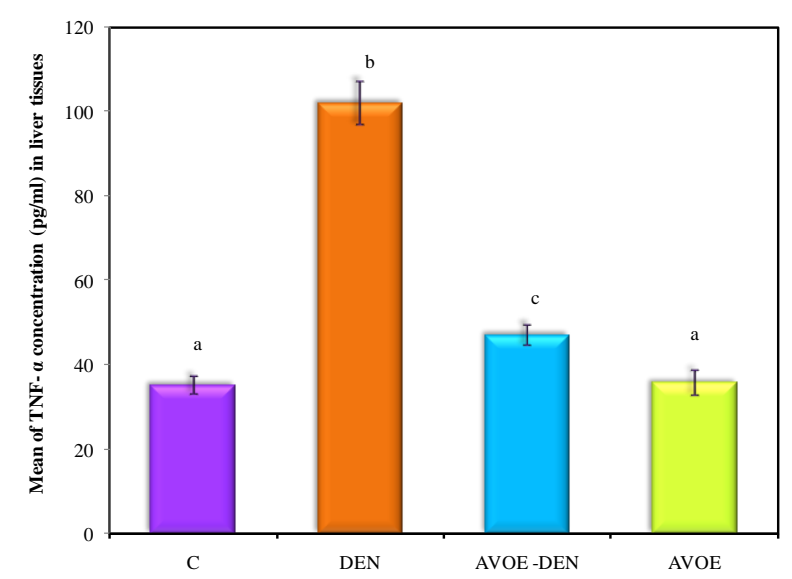

(c)

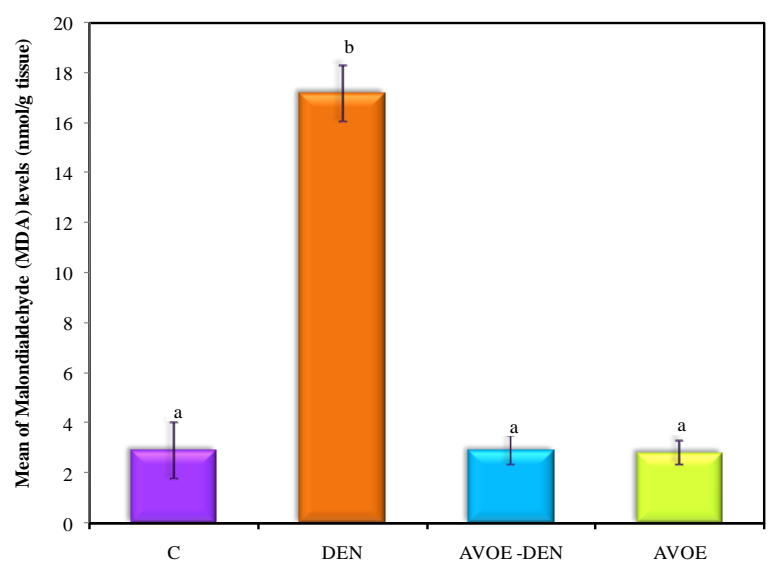

(e)

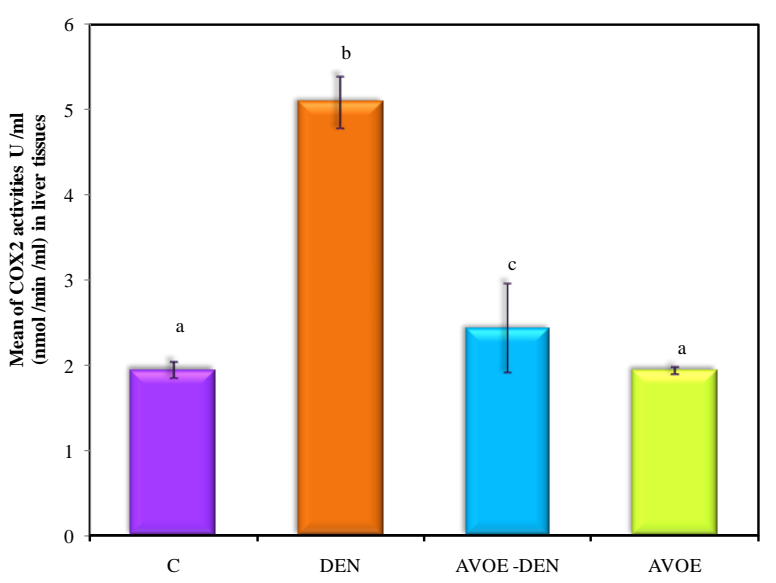

(b)

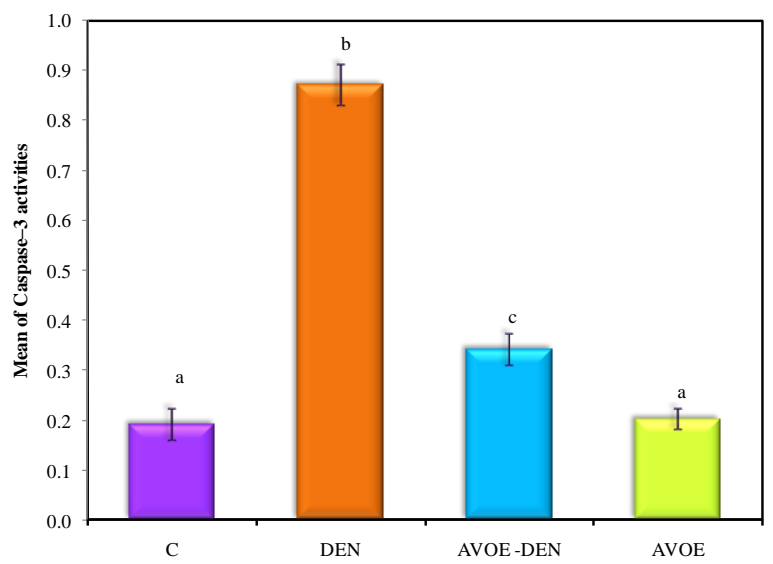

(d)

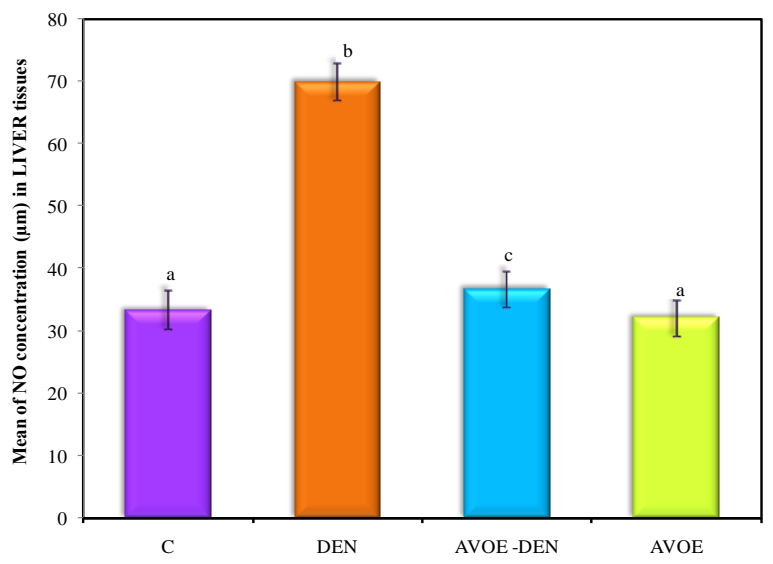

(f)

Fig. 1 Biochemical parameters of different studied groups. (a): Lipoxygenase, LOX, activities ( $\mu \mathrm{mol} / \mathrm{mg}$ protein) in liver tissues; (b): COX2 activities $U / \mathrm{mL}(\mathrm{nmol} / \mathrm{min} / \mathrm{mL})$ in liver tissues; (c): TNF- $\alpha$ concentration (pg/mL) in liver tissues; (d): Caspase-3 activities; (e): Malondialdehyde (MDA) levels (nmol/g tissue); (f): NO concentration ( $\mu \mathrm{m})$ in LIVER tissues.

ALT, AST and bilirubin levels were $(0.80 \pm 0.08$ $\mathrm{U} / \mathrm{L}, 15.41 \pm 1.29 \mathrm{U} / \mathrm{L}, 0.76 \pm 0.19 \mathrm{mg} / \mathrm{dL})$ lower than 
that in DEN group $(4.55 \pm 0.16 \mathrm{U} / \mathrm{L}, 20.2 \pm 2.01 \mathrm{U} / \mathrm{L}$, $1.99 \pm 0.08 \mathrm{mg} / \mathrm{dL}$ ) $; P<0.05$ (Table 1 ). ALT, AST and bilirubin levels in AVOE-DEN were $(2.47 \pm 0.29 \mathrm{U} / \mathrm{L}$, $16.23 \pm 1.99 \mathrm{U} / \mathrm{L}, 1.12 \pm 0.09 \mathrm{mg} / \mathrm{dL})$ compared to DEN group $P<0.05$. ALT, AST and bilirubin levels in AVOE were $(0.81 \pm 0.19 \mathrm{U} / \mathrm{L}, 15.44 \pm 1.71 \mathrm{U} / \mathrm{L}, 0.77 \pm$ $0.08 \mathrm{mg} / \mathrm{dL}$ ) compared to control group $P<0.05$ (Table 1).

\subsection{Lipid Profile}

TC, TG and LDL-C levels were $(66.64 \pm 3.17 \mathrm{mg} / \mathrm{dL}$, $78.79 \pm 1.84 \mathrm{mg} / \mathrm{dL}, 35.75 \pm 0.57 \mathrm{mg} / \mathrm{dL}$ ) lower than that in DEN group $(202.99 \pm 3.02 \mathrm{mg} / \mathrm{dL}, 168.74 \pm$ $2.41 \mathrm{mg} / \mathrm{dL}, 160.80 \pm 1.02 \mathrm{mg} / \mathrm{dL}$ ) while HDL-C in DEN $14.14 \pm 3.42 \mathrm{mg} / \mathrm{dL}$ lower than that in C $22.99 \pm$ $1.91 \mathrm{mg} / \mathrm{dL}$ ); $P<0.05$ (Table 1). TC, TG, HDL-C and LDL-C levels in AVOE-DEN were (102.42 \pm 3.26 $\mathrm{mg} / \mathrm{dL}, 92.71 \pm 2.26 \mathrm{mg} / \mathrm{dL}, 22.93 \pm 1.86 \mathrm{mg} / \mathrm{dL}$, $36.63 \pm 0.42 \mathrm{mg} / \mathrm{dL})$ compared to DEN group $P<0.05$. TC, TG, HDL-C and LDL-C levels in AVOE were $(65.97 \pm 2.89 \mathrm{mg} / \mathrm{dL}, 77.99 \pm 1.91 \mathrm{mg} / \mathrm{dL}, 23.01 \pm$
$1.60 \mathrm{mg} / \mathrm{dL}, 34.98 \pm 0.26 \mathrm{mg} / \mathrm{dL})$ compared to control group $P<0.05$ (Table 1$)$.

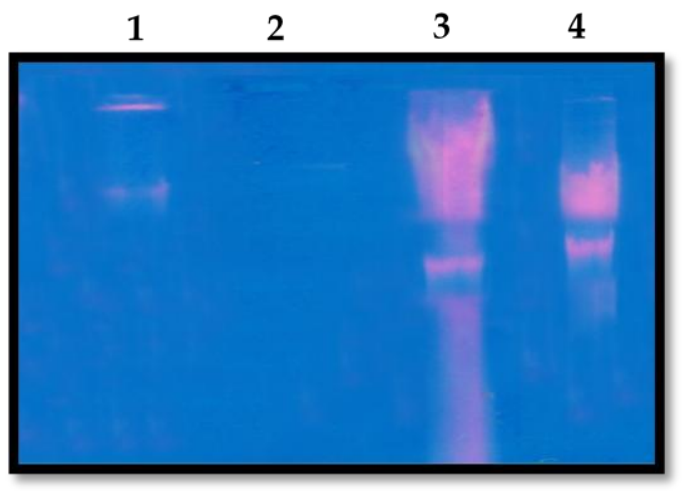

Fig. 2 DNA fragmentation of different studied group in liver tissue. The agarose gel electrophoresis showed very low or undetectable DNA laddering (DNA fragmentation) in the hepatocytes. The DNA intact band appears to be condensed near the application point with no DNA smearing suggesting no DNA fragmentation control (lane 1). Treatment with AVOE alone shows no DNA fragmentation (lane 2). Otherwise, DEN administration resulted in a massive DNA fragmentation compared to $\mathrm{C}$ (lane 3). Treatment with AVOE pre, during, and post DEN administration decreased DNA fragmentation compared to treatment with DEN alone (lane 4).

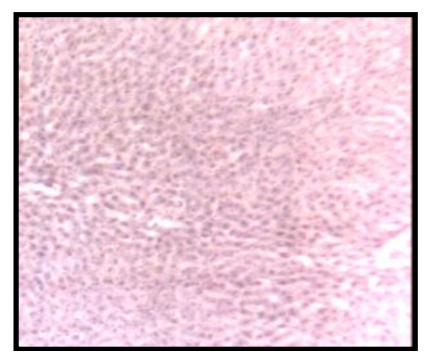

(a)

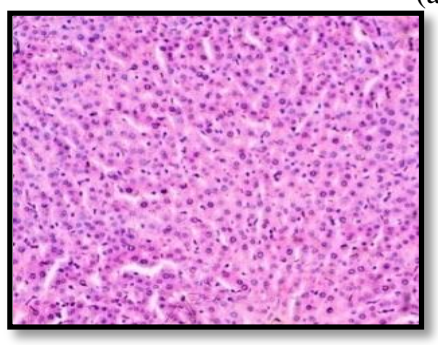

(c)

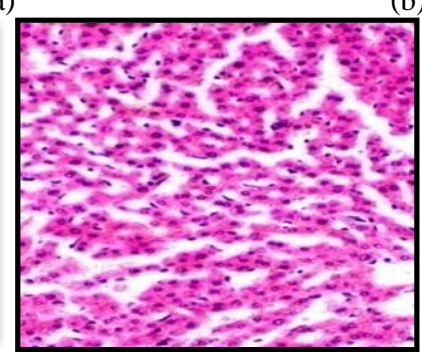

(d)

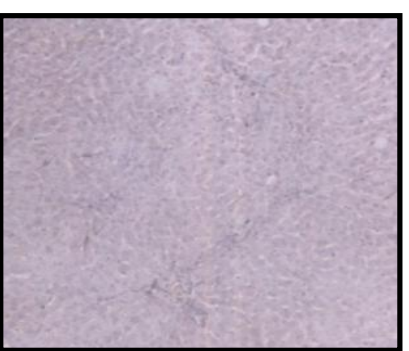

(b)

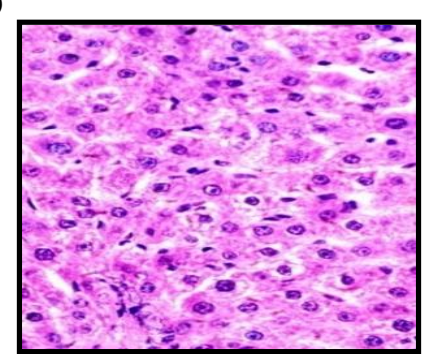

(e)

Fig.3 Histopathology examination of different studied groups. (a): Microscopic examination of control reveals hepatic tissue showing presewed architecture no remarkable pathologic changes (H and E stain, $x$ 100); (b): AVOE-DEN (Microscopic examination of Avocado extract) reveals hepatic tissue showing presewed architecture with mild periportal inflammatory reaction (H and $\mathrm{E}$ stain, $\mathrm{x}$ 100); (c): Liver histopathological examination of DEN group histopathological effects of DEN showed mild to moderate periportal inflammation (H and E stain, $x$ 100); (d): Liver histopathological examination of (AVOE), normal hepatic tissue, showing normal large polygonal cells with round nuclei and eosinophilic cytoplasm. Hepatocytes are arranged in plates separated by hepatic sinusoids. Hepatocytes radiate out from the terminal venule (H and $\mathrm{E}$ stain, $\mathrm{x}$ 100); (e): DEN Microscopic examination reveals hepatic tissue showing liver cells with mild dysplastic nuclei, preminent nucleoli, 
binucleated cells ( $\mathrm{H}$ and $\mathrm{E}$ stain, $\mathbf{x} 250$ ).

\subsection{Histopathologic Results}

Histopathological examination of control group showed normal rat liver with no remarkable pathological changes (Fig. 3a). DEN administration showed mild dysplastic nuclei, preminent nucleoli, binucleated cells, and mild to moderate periportal inflammation (Figs. 3c and 3e). Examination of rat liver treated with AVOE before, during and post DEN showed normal liver architecture with mild periportal inflammatory reaction (Fig. 3b). AVOE treatment showed normal large polygonal cells with round nuclei and eosinophilic cytoplasm. Hepatocytes are arranged in plates separated by hepatic sinusoids (Fig. 3d).

\section{Discussion}

Liver is an important organ in regulating host defense mechanisms such as immunological, biochemical, and metabolic functions including the metabolism of xenobiotics and drugs. ROS (reactive oxygen species) and free radicals are important mediators of several forms of tissues damage including liver tissue $[4,25]$. Several possible signaling pathways have been described linking ROS to hepatocyte apoptosis. These include cell surface death receptors (extrinsic) and mitochondria (intrinsic) pathways [26]. ROS may act as growth inhibitory and apoptotic signaling agents, MDA is a major oxidation product of peroxidized polyunsaturated fatty acids, and increased MDA content is an important indicator of lipid peroxidation $[4,25]$. The present study has shown a significant elevation in the levels of MDA, NO, caspase-3, DNAF, TNF- $\alpha$, COX-2, LOX, TP as well as serum lipid profile and liver functions in DEN as compared to control, this indicated that DEN induced oxidative stress, apoptosis and inflammation. Formations of free radicals which play an important role in the pathogenesis of liver injuries are response to DEN administration. DEN induces iNOS gene expression and generates NO radicals which react nonenzymatically with super oxide radicals $\left(\mathrm{O}^{2-}\right)$ forming peroxynitrite $(\mathrm{ONOO}-\mathrm{a}$ reactive nitrogen species). A reactive nitrogen species can oxidize nuclear DNA and cell protein [27, 28]. Free radicals led to accelerate peroxidation of native membrane lipids such as mitochondrial membrane, loss of cell integrity, increase in membrane permeability, and alteration of $\mathrm{Ca}^{2+}$ homeostasis that contribute to elevation in caspase-3 activities, DNAF and inflammatory mediators (TNF- $\alpha$ ). This mean that DEN causes apoptosis, that is an adaptive process to combating excessive damage, and led to liver injuries [4, 25].

TNF- $\alpha$ elevation in our study was accompanied by elevation of COX-2, LOX activities and NO level compared to control. These results agreed other investigator who reported that TNF- $\alpha$ induces inflammatory genes such as COX-2, LOX, and iNOS $[29,30]$. NO increases the production of PGE2 by direct activation of COX [31].

Administration of DEN induced liver injuries and leakage of hepatocytes cytosolic contents and this led to an increases in the activities of serum AST, ALT, and bilirubin level compared to the controls. The increase in activity reflects the pathological alteration in biliary flow and discharge of total bilirubin reflects a non-specific alteration in the plasma membrane integrity and/or permeability [12]. Our data also showed an increase of liver TP level in DEN group and this may be due related to the elevation of protein expression towards liver apoptosis process [32, 33]. There were increases in the levels of TC, T.G and LDL-Ch with a decline HDL-Ch level in DEN group compared with the controls and this was related to liver inflammation. Elevation in LDL caused endothelial cell apoptosis [34]. The histopathological results confirmed the biochemical results. Liver histopathological examination of control showed normal rat liver with no remarkable pathologic changes where administration DEN showed mild dysplastic nuclei, preminent nucleoli, binucleated cells and mild 
to moderate periportal inflammation.

Consumption of fruits and vegetables is associated with a lowered risk of many diseases by targeting many mechanisms such as cell cycle, signal transduction, oncogenesis, transcription, antioxidant metabolism enzymes and apoptosis, etc. [5, 11]. Apoptosis appears as an important target by avocado phytochemicals in selectively eliminating cancer cells from normal tissues $[6,35]$. This finding agree with our results, where the present study showed no significant differences in the levels of MDA, NO, caspase-3, DNAF, TNF- $\alpha$, COX-2, LOX, TP as well as serum lipid profile and liver functions in AVOE group as compared to control, while there are a significant improve in the levels of MDA, NO, caspase-3, DNAF, TNF- $\alpha$, COX-2, LOX, $\mathrm{TP}$ as well as serum lipid profile and liver functions in AVOE-DEN group as compared to DEN, this may be due to the effect of avocado phytochemical composition. Where avocado phytochemicals play a selective role in quenching the free radicals resulted from the metabolism of DEN, thereby inhibiting lipid peroxidation and protecting membrane lipids from oxidative damage, inhibited caspase- 3 enzyme and DNAF in turn prevent apoptosis, consequently, decrease in total protein toward apoptosis as well as decrease in inflammation and inflammatory mediator (TNF- $\alpha$, COX-2, LOX).

Avocado consumption provides monounsaturated fatty acids, fiber, Vitamins $\mathrm{B}$ and $\mathrm{E}$ and phytosterols, b-sitosterol, carotenoids, leutin which have been shown to exert potent anti-oxidant, anti-inflammatory, anticholesterolemic, anticancer agent [36-40]. Some investigators found that, avocado decreased and suppressed gene expression of TNF-alpha, IL-1beta, COX-2, iNOS as well as decreased prostaglandin E2 and nitric oxide production in articular chondrocytes and monocyte/macrophages and decreased cartilage catabolism [39, 41-43].

The results of present study agree with other investigators who reported that, the phytosterols lowering effect mechanism on the serum triglyceride, total cholesterol, and LDL-cholesterol involves inhibition of intestinal cholesterol absorption, decrease in hepatic cholesterol synthesis, increases catabolism of lipid accumulated in adipose tissue causing a decrease in body weight and a highly significant rise in HDL-cholesterol levels, and improve AST and ALT enzymes [11, 44, 45]. Other investigator found that avocado oil administration revealed the beginning of a regeneration of liver function [9]. The histopathological results confirmed the biochemical results. Liver histopathological examination of AVOE-DEN showed normal liver architecture with mild periportal inflammatory reaction as compared to DEN. AVOE treatment showed normal large polygonal cells with round nuclei and eosinophilic cytoplasm. Hepatocytes are arranged in plates separated by hepatic sinusoids.

\section{Conclusion}

(1) DEN induces oxidative stress, inflammation, apoptosis and toxicity for liver tissues.

(2) AVOE (Avocado extract) administration in rats for 5 weeks has no toxic effect on liver tissues.

(3) The present study showed that (AVOE) extract exerts a significant protective effect against DEN induced oxidative stress, inflammation and apoptosis by augmenting host antioxidant defense mechanisms and improve apoptosis and cell cycle mechanisms in rat in liver tissues. This extract is a promising agent for the prevention of chemical induced toxicity through enhancing the ant oxidative and drug metabolizing enzymes, as well as lowering the extent of lipid peroxidation.

(4) Avocado extract plays a role as anticholesterolemic agent.

\section{References}

[1] Elmore, S. 2007. "Apoptosis: A Review of Programmed Cell Death.” Toxicologic Pathology 35 (4): 495-516.

[2] Schulte-Herman, R., Bursch, W., and Marian, B. 1999. "Active Cell Death (Apoptosis and Cellular Proliferation as Indicators of Exposure to Carcinogens." IARC Scientific Publications (lyon) 146: 273-85. 
[3] Katayama, M., Sugie, S., Yoshimi, N., Yamada, Y., Sakata, K., Qiao, Z., Iwasaki, T., Kobayashi, H., and Mori, H. 2003. "Preventive Effect of Fremented Brown Rice and Rice Bran on Diethylnitrosoamine and Phenobarbital, Induced Hepatocarcinogensis in Male F344 Rats." Oncology Reports 10: 875-80.

[4] Shaban, N. Z., El-Kersh, M. A., Bader-Eldin, M. M., Kato, S. A., and Hamoda, A. F. 2014. "Effect of Punica Granatum (Pomegranate) Juice Extract on Healthy Liver and Hepatotoxicity Induced by Diethylnitrosamine and Phenobarbital in Male Rats." J. Med. Food 17 (3): 339-49.

[5] Ding, H., Han, C., Guo, D., Chin, Y., Yi, D., Kinghorn, D., and D'Ambrosio, M. 2009. "Selective Induction of Apoptosis of Human Oral Cancer Cell Lines by Avocado Extracts Via a ROS-Mediated Mechanism." Nutrition and Cancer 61 (3): 348-56.

[6] Ding, H., Chin, Y. W., Kinghorn, A. D., and D'Ambrosio, S. M. 2007. "Chemopreventive Characteristics of Avocado Fruit.” Semin. Cancer Biol. 17 (5): 386-94.

[7] María, P. R., Alicia, O. M., Germán, C. C., María, H. N., Leticia, G. S., Hugo, N. M., and Marcela, H. O. 2012. "Hypolipidemic Effect of Avocado (Persea Americana Mill) Seed in a Hypercholesterolemic Mouse Model." Plant Foods Hum. Nutr. 67: 10-6.

[8] Ana, O., Eryvelton, F., Rafaella, B., Daniele, C., Rebeca, M., Camila, A., Antonio, S., Paloma, M., Teresinha, S., Alexandre, G., and Maria, H. 2013 "Effect of Semisolid Formulation of Persea Americana Mill (Avocado) Oil on Wound Healing in Rats." Publishing Corporation Evidence-Based Complementary and Alternative Medicine 2013: 472382. doi: 10.1155/2013/472382.

[9] Octavio, C. Z., Cirilo, N. H., Ma. A. U., Guadalupe, S., Patricia, H. J., and Dulce, M. 2014. "Effect of Dietary Intake of Avocado Oil and Olive Oil on Biochemical Markers of Liver Function in Sucrose-Fed Rats." Publishing Corporation BioMed Research International 2014: 595479. doi: 10.1155/2014/595479.

[10] David, O., Sue, C., James, S., Fayek, N., and Mary, L. 2012. "Influence of Maturity and Ripening on Aroma Volatiles and Flavor in 'Hass' Avocado." Postharvest Biology and Technology 71: 41-50.

[11] Mohammed, S. Al-D. 2011. "Hypolipidemic and Antioxidant Activities of Avocado Fruit Pulp on High Cholesterol Fed Diet in Rats". African Journal of Pharmacy and Pharmacology 5 (12): 1475-83.

[12] Singh, B. N., Singh, B. R., Sarma, B. K., and Singh, H. B. 2009. "Potential Chemoprevention of N-nitro Sodiethylamine-Induced Hepatocarcinogenesis by Polyphenolics from Acacia Nilotica Bark." Chemico-Biological Interaction 181: 20-8.

[13] Butt, A. J., Roberts, C. G., Seawright, A. A., Oelrichs, P.
B., Macleod, J. K., Liaw, T. Y., Kavallaris, M., Somers-Edgar, T. J., Lehrbach, G. M., Watts, C. K., and Sutherland, R. L. 2006. "A Novel Plant Toxin, Persin, with in Vivo Activity in the Mammary Gland, Induces Bim-Dependent Apoptosis in Human Breast Cancer Cells." Mol. Cancer Ther. 5 (9): 2300-9.

[14] Tsuyosh, O. S., James, B. K. 1978 “A Simplified Method of Quantitating Protein Using the Biuret and Phenol Reagent." Anal. Biochem. (86):193-200.

[15] Haining, J. L., and Axelord, B. 1958. "Induction Period in the Lipoxidase-Catalyzed Oxidation of Linoleic Acid and Its Abolition by Substrate Peroxide." J. Biol. Chem. 232 (1): 193-202.

[16] Smith, C. J., Zhang, Y., Koboldt, C. M., Muhammad, J., Zweifel, B. S., Shaffer, A., Talley, J. J., Masferrer, J. L., Seibert, K., and Isakson, P. C. 1998. "Pharmacological Analysis of Cyclooxygenase-1 in Inflammation." Proc. Natl. Acad. Sci. USA 95 (22): 13313-8.

[17] Brouckaert, P. 1993. "Tumor Necrosis Factor, Its Receptors and the Connection with Interleukin I and Interleukin 6." Immunobiology 187: 317-29.

[18] Talanian, R. V., Quinlan, C., Trautz, S., Hackett, M. C., Hackett, J. A., Banach, D., Ghayur, T., Brady, K. D., and Wong, W. W. 1997. "Substrate Specificities of Caspase Family Proteases.” J. Biol. Chem. 272: 9677-82.

[19] Li, X., Fu, G. F., Fan, Y. R., Shi, C. F., Liu, X. J., Xu, G. X., and Wang, J. J. 2003. "Potent Inhibition of Angiogenesis and Liver Tumor Growth by Administration of an Aerosol Containing a Transferrin-Liposome Endostatin Complex." World J. Gastroenterol 9: 262-6.

[20] Montgomery, H., and Dymock, J. 1961. "The Determination of Nitrite in Water." Analyst 86: 414-6.

[21] Ohkawa, H., Ohishi, N., and Yagi, K. 1979. "Assay for Lipid Peroxides in Animal Tissues by Thiobarbituric Acid Reaction.” Anal. Biochem. 95: 351-8.

[22] Jendrassik, L. 1938. "Determination of Bilirubin in Serum of Rat." Biochem. 297: 81-9.

[23] Reitman, S., and Frankel, S. 1957. "A Colorimetric Method for the Determination of Serum Glutamic Oxalacetic and Glutamic Pyruvic Transaminases.” Am. J. Clin. Path. 28 (1): 56-63.

[24] Burstein, M. 1970. "Rapid Method for the Isolation of Lipoproteins from Human Serum by Precipitation with Polyanions." Lipid. Res. (11): 583-95.

[25] Shaban, N. Z., Helmy, M. H., El-Kersh M. A. R., and Mahmoud, B. F. 2003. "Effects of Bacillius Thuringiensis Toxin on Hepatic Lipid Peroxidation and Free-Radical Scavengers in Rats Given Alpha-Tocopherol or Acetylsalicylate." Comp. Biochem. Physiol. C. 135: 405-14.

[26] Jin, Z., and El-Deiry, W. S. 2005. "Overview of Cell Death Signaling Pathways." Cancer Biol. Ther. 4: 139-63. 
[27] Bishayee, A., Barnes, K. F., Bhatia, D., Darvesh, A. S., and Carroll, R. T. 2010. "Resveratrol Suppresses Oxidative Stress and Inflammatory Response in Diethylnitrosamine-Initiated Rat Hepatocarcinogenesis." Cancer Prev. Res. 3: 753-63.

[28] Ohta, T., Takahashi, M., and Ochiai, A. 2006. "Increased Protein Expression of both Inducible Nitric Oxide Synthase and Cyclooxygenase-2 in Human Colon Cancers." Cancer Letters 239: 246-53.

[29] Gonzalez, E., Ramirez-Mares, M. V., and Puangpraphant, S. 2009. "Bioactive Components of Tea: Cancer, Inflammation and Behavior." Brain Behavior Immunity 23: 721-31.

[30] Kim, K. H., Kim, S. H., Kim, S. H., Back J. H., Park M. J., Kim J. M. 2006. "Cyclooxygenase-2 and Inducible Nitric Oxide Synthase Expression in Thyroid Neoplasms and Their Clinicopathological Correlation." J. Korean Med. Sci. 21: 1064-9.

[31] Salvemini, D., Misko, T. P., Masferrer, J. L., Seibert, K., Currie, M. G., and Needleman, P. 1993. "Nitric Oxide Activates Cyclooxygenase Enzymes." Proc. Natl. Acad. Sci. USA 90: 7240-4.

[32] Kaufman, K. A., James, G., Sheedy, D., Harper, C., and Matsumoto, I. 2006. "Differential Protein Expression in the Perfrontal White Matter of Human Alcoholics: A Proteomics Study Molecular Psychiatry."Molecular Psychiatry 11: 56-65.

[33] Petrak, J., Myslivcova, D., Man, P., Cmejla, R., Cmejlova, J., and Vyoral, D. 2006. "Proteomic Analysis of Iron Over Load in Human Hepatoma Cells."AMJ Physiol. Gastro. Intest. Liver Physiol. 290: G1059-66.

[34] Florian, M., Magder, S. 2008. "Estrogen Decreases TNF- $\alpha$ and Oxidized LDL Induced Apoptosis in Endothelial Cells." Steroids 73: 47-58.

[35] Nichenametla, S. N., Taruscio, T. G., Barney, D. L., and Exon, J. H. 2006. "A Review of the Effects and Mechanisms of Polyphenolics in Cancer." Crit. Rev. Food Sci. Nutr. 46: 161-83.

[36] Wang, W., Bostic, T. R., and Gu, L. 2010. “Antioxident Capacities, Procyanidins and Pigments in Avocados of Different Strains and Cultivar."Food Chem. 122: 1193-8.

[37] Weihrauch, J. L., and Gardner J. M. 1978. "Sterol Content of Foods of Plant Origin.” J. Am. Diet. Assoc. 73: 39-47.

[38] Moghadasian, M. H., and Frohlich, J. J. 1999. "Effects of Dietary Phytosterols on Cholesterol Metabolism and Atherosclerosis: Clinical and Experimental Evidence." Am. J. Med. 107: 588-94.

[39] Heinecke, L. F., Grzanna, M. W., Au, A. Y., Mochal, C. A., Rashmir-Raven, A., Frondoza, C. G. 2010. "Inhibition of Cyclooxygenase-2 Expression and Prostaglandin E2 Production in Chondrocytes by Avocadosoybean Unsaponifiables and Epigallocatechin Gallate.” Osteoarthritis Cartilage 18 (2): 220-7.

[40] Lu, Q. Y., Arteaga, J. R., Zhang, Q., Huerta, S., Go, V. L., and Heber D. 2005. "Inhibition of Prostate Cancer Cell Growth by an Avocado Extract: Role of Lipid-Soluble Bioactive Substances." J. Nutr. Biochem. 16: 23-30.

[41] Au, R. Y., Al-Talib, T. K., Au, A. Y., Phan, P. V., and Frondoza, C. G. 2007. "Avocado SoyBean Unsaponifiables (ASU) Suppress TNF- $\alpha$ IL-1 $\beta$, COX-2, iNOS Gene Expression, and Prostaglandin E2 and Nitric Oxide Production in Articular Chondrocytes and Monocyte/Macrophages." Osteoarthritis Cartilage 15 (11): 1249-55.

[42] Boileau, C., Martel-Pelletier, J., Caron, J., Msika, P., Guillou, B., Baudouin, C., and Pelletier, J. P. 2009. "Protective Effects of Total Fraction of Avocado/Soybean Unsaponifiables on the Structural Changes in Experimental Dog Osteoarthritis: Inhibition of Nitric Oxide Synthase and Matrix Metalloproteinase-13." Arthritis Research and Therapy 11: R41.

[43] Ownby, S. L., Fortuno, L. V., Au, A. Y., Grzanna, M. W., Rashmir-Raven, A. M., and Frondoza, C. G. 2014. "Expression of Pro-inflammatory Mediators Is Inhibited by an Avocado/Soybean Unsaponifiables and Epigallocatechin Gallate Combination." J. Inflamm. (Lond) 11 (1): 8.

[44] Ikeda, I., and Sugano, M. 1983. "Some Aspects of Mechanism of Inhibition of Cholesterol Absorption by Beta-Sitosterol." Biochim. Biophys. Acta. 732: 651-8.

[45] Shehata, M. M. S. M., and Soltan, S. S. A. 2013. "Effects of Bioactive Component of Kiwi Fruit and Avocado (Fruit and Seed) on Hypercholesterolemic Rats." World Journal of Dairy and Food Sciences 8 (1): 82-93. 